\title{
A new interpretation of Stephanian deformation in the Decazeville basin (Massif Central, France): consequences on late Variscan tectonism
}

\author{
Christophe Basile \\ LGCA, CNRS UMR 5025, OSUG, UJF \\ Maison des Géosciences, BP 43, 38041 Grenoble Cedex, France \\ tel 33476514069 \\ fax 33476514058 \\ cbasile@ujf-grenoble.fr
}

\begin{abstract}
Five stages of faulting were observed in and around the Stephanian Decazeville basin, in the SW French Massif Central, at the southern edge of the Sillon houiller fault. The older stage ends during middle Stephanian time, and corresponds to a strike-slip regime with $\mathrm{N}-\mathrm{S}$ shortening and E-W extension. Before the end of the middle Stephanian, three other stages were recorded: two strike-slip regimes with NW-SE, then E-W compression and NE-SW, then N-S extension; and finally a NNE-SSW extensional regime during the main subsidence of the basin from the end of the middle Stephanian to late Stephanian. Based on mining documents, a new interpretation of the N-S striking folds of the Decazeville basin is proposed. Folding may not be associated with $\mathrm{E}-\mathrm{W}$ compression but with diapirism of coal seams along syn-sedimentary normal faults during the extensional phase. A last strike-slip regime with N-S compression and E-W extension may be related to Cainozoic Pyrenean orogeny. At a regional scale, it is suggested that from the end of the middle Stephanian to the late Stephanian, the main faults in the Decazeville basin may represent a horsetail splay structure at the southern termination of the Sillon houiller fault.
\end{abstract}

Key words: strike-slip faults / stress / Sillon houiller fault / Argentat fault / coal deformation 


\section{Introduction}

During the Variscan orogeny, the Stephanian time represents a key period between late- and post-orogenic stages. During the Westphalian, outward thrusting and associated folding in foreland basins (Cantabria, the Ruhr basin) recorded the end of continental convergence. At the same time, in the internal zones, synkinematic plutonism accommodated extension parallel to the Variscan belt (Faure, 1995). During the Permian, widespread extension affected the whole Variscan belt, resulting in numerous and deep continental basins (Ménard and Molnar, 1988). The Stephanian represents a transition between these two endmembers. At that time, the deformation of the Variscan belt was controlled by numerous strike-slip faults, associated with intracontinental coal-bearing basins. This paper focus on this Stephanian tectonic evolution, based on the study of the Decazeville basin, associated with the Sillon houiller fault, one of the most important Stephanian strike-slip fault.

\section{Geological setting}

The Decazeville basin is located SW of the French Massif Central, near the intersection of two major late-Hercynian faults, the Sillon houiller and Argentat faults (Fig. 1a). The Sillon houiller fault is a $270 \mathrm{~km}$-long, nearly N-S striking fault, that crosses the entire Massif Central. It is lined up southward with the Villefranche fault, and possibly prolongates northward below the Paris basin. In the Massif Central, the Sillon houiller was a left-lateral strike-slip fault, that accommodated ductile deformation probably during the Westphalian, then brittle deformation coeval with the formation of numerous deep and narrow Stephanian basins (Letourneur, 1953). The cumulated horizontal displacement has been estimated to be less than one hundred kilometers (Grolier and Letourneur, 1968). This fault has been considered as a transfer fault that accommodated either differences in the directions of extension during Namurian and early Stephanian times (Burg et al., 1990), or differences in the amount of extension during Stephanian and Autunian times (Faure, 1995).

The Argentat fault is a $160 \mathrm{~km}$-long curved fault in the western part of the Massif Central, from the Bosmoreau Carboniferous basin in the north to the Decazeville basin in the south. This fault strikes N-S in its northern part, and NWSE in its southern part. Some authors proposed that the NNE-SSW striking Villefranche fault is its southernmost continuation (Mouret, 1910; Raguin, 1928). The Argentat fault was first a right-lateral ductile normal fault, then a brittle strike-slip fault during the late Carboniferous (Feix et al., 1987; Roig et al., 1997).

Many Stephanian basins formed along these two major faults: for example Noyant, Saint Eloy, Messeix, Champagnac basins along the Sillon houiller fault (Letourneur, 1953), St Perdoux-Lacapelle-Marival (Vetter, 1968) and Argentat basins (Genna et al., 1998) associated with the Argentat fault zone (Fig. 1a). In these basins, the age of the sedimentary infilling has been determined from continental floras, even if it does not allow very precise stratigraphic attributions (Broutin et al., 1986; Becq-Giraudon, 1993). The sediments are mainly middle 
Stephanian (Stephanian B) in age, with early Stephanian (A) suspected in the St Perdoux basin, and the base of late Stephanian (C) observed in the Decazeville basin (Fig. 1c) (Vetter, 1968). Volcanism is frequently associated with the first sediments infilling the Stephanian basins. However, the age of volcanism is controversial in the Decazeville basin: from palynology, the older sediments of the Decazeville basin were dated from the base of middle Stephanian (Vetter, 1968), whereas U-Pb dating on volcanic zircons provided an older age (Visean: $333 \mathrm{Ma}$ ) (Bruguier et al., 1998). The Decazeville basin is filled by up to $1.8 \mathrm{~km}$ of mainly detrital (lacustrine and deltaic) Stephanian sediments (Fig. 1c), unconformably covered eastward by Permian sediments in the Rodez Straits basin (Vetter, 1968). The main structural features of the Decazeville basin are N-S trending horsts, grabens and folds (Figs. $1 \mathrm{~b}$ and 1d). Coal seams increased in thickness up to $60 \mathrm{~m}$ in anticline hinges.

Previous structural studies (Bonijoly and Castaing, 1983; Blès et al., 1989) reconstructed three tectonic phases during Stephanian times from micro- and macro-structures, in the Decazeville basin as in the whole Massif Central (Fig. 2):

- a strike-slip regime with N-S shortening: $\mathrm{N} 010^{\circ} \mathrm{E}$ to $\mathrm{N} 050^{\circ} \mathrm{E}$ (sub-parallel to the Sillon houiller fault) left-lateral strike-slip faults are associated with $\mathrm{N} 140^{\circ} \mathrm{E}$ to $\mathrm{N} 170^{\circ} \mathrm{E}$ (sub-parallel to Argentat fault) right-lateral strike-slip faults, and with $\mathrm{N} 080^{\circ} \mathrm{E}$ to $\mathrm{N} 120^{\circ} \mathrm{E}$-striking reverse faults. Because of the age of affected sediments, and especially because the Banel Formation is deformed in the Decazeville basin, this phase has been dated as middle Stephanian in age (Bonijoly and Castaing, 1983).

- a strike-slip regime with NW-SE shortening: N120 $\mathrm{E}$ dextral strike-slip faults associated with $\mathrm{N} 160^{\circ} \mathrm{E}$ to $\mathrm{N}-\mathrm{S}$ sinistral strike-slip faults, and with $\mathrm{N} 030^{\circ} \mathrm{E}$ folds. In the Rodez Straits area, NW-SE syn-sedimentary normal faults are also related to this regime. As the previous one, this phase affected the Banel Formation in the Decazeville basin.

- an E-W shortening expressed by $\mathrm{N} 060^{\circ} \mathrm{E}$ to $\mathrm{N} 080^{\circ} \mathrm{E}$ dextral strike-slip faults, $\mathrm{E}-\mathrm{W}$ to $\mathrm{N} 140^{\circ} \mathrm{E}$ sinistral strike-slip faults, $\mathrm{N} 160^{\circ} \mathrm{E}$ to $\mathrm{N} 010^{\circ} \mathrm{E}$ reverse faults and $\mathrm{N} 150^{\circ} \mathrm{E}$ to $\mathrm{N}-\mathrm{S}$ folds. This phase may not be older than the end of Stephanian, because it is never observed in the latest Stephanian or in Autunian sediments, whereas it folds the middle to late Stephanian formations in the Decazeville basin.

This counterclockwise rotation of the shortening direction from N-S to E-W has been interpreted (Bonijoly and Castaing, 1987; Blès et al., 1989) as a result of the decreasing dextral shear of the European Variscan belt at the end of the orogeny (Arthaud and Matte, 1977).

In this paper I present the results of a microstructural study in and around the Decazeville basin, following two perpendicular sections: one from the NE border of the Decazeville basin to the Lacapelle-Marival basin (Fig. 1a); the other from SW to NE across the northern end of the Decazeville basin, perpendicular to the Argentat fault direction (Fig. 1b). This study provides new data which require a new interpretation of folding in the Decazeville basin, and consequently of the post-orogenic tectonic evolution in the French Massif Central during Stephanian 
times.

\section{Observations}

This study is mainly based on fault analysis, with 250 slickensides measured at ten sites (Fig. 1b) in the crystalline basement or Stephanian formations. The main observations are summarized in Figure 3. From field observations (striation superpositions, fault intersections), five successive fracture sets were distinguished and sorted. As the five fracture sets were not observed in all sites, the evolution is deduced from the whole data set, with the assumption that comparable faults or states of stress were contemporaneous. The succession of deformations as presented below minimizes the number of deformation stages, but is not the only one possible. Stress tensors were determined from fault and striae sets using a direct inversion method (Angelier, 1990) that minimizes the angles between computed and observed striations. All stress tensors have been computed site by site, then regionally. For each site, the angular difference between observed and computed striations does not exceed $20^{\circ}$.

The older fault set affected only the basement on each side of the Sillon houiller fault and the volcanic rocks at the base of the basinal sequence. This set is then either younger than the Visean or than the base of middle Stephanian, depending on the age of the volcanic formation. This first set includes N-S to NW-SE dextral strike-slip faults associated with WSW-ENE to SSW-NNE sinistral strike-slip faults (I, Fig. 3). Two sites (Capendu and Bois) show a 20 to $30^{\circ}$ progressive counterclockwise rotation of the faults and striations. At Bois, this rotation is also recorded by two successive sets of veins (Fig. 3). The associated state of stress is defined by a maximum principal stress $(\sigma 1)$ trending $\mathrm{N} 020^{\circ} \mathrm{E}$ (then $\mathrm{N} 170^{\circ} \mathrm{E}$ ), a minimum principal stress $(\sigma 3)$ trending $\mathrm{N} 110^{\circ} \mathrm{E}$ (then $\mathrm{N} 090^{\circ} \mathrm{E}$ ), and the intermediate principal stress $(\sigma 2)$ almost vertical (I, Fig. 3 ).

The counterclockwise rotation of fault planes is also observed in a second set of faults, made of NW-SE dextral strike-slip and associated N-S sinistral strikeslip faults (II, Fig. 3). $\sigma 1$ and $\sigma 3$ are then trending $\mathrm{N} 145^{\circ} \mathrm{E}$ and $\mathrm{N} 055^{\circ} \mathrm{E}$, respectively. At Site RD218 (top of Banel Formation), this second set includes faults at the contact between basement and sediments. Consequently this fault set is at least contemporaneous with the middle Stephanian sediments.

The third fault set recorded an inversion of shear directions: NW-SE strike-slip faults are left-lateral, and NE-SW strike-slip faults are right-lateral. They are associated with N-S reverse faults, sediments folded and detached from the basement (RD218, Fig. 3) and E-W normal faults accommodating a NNW-SSE extension $\left(\sigma 1\right.$ trending $\mathrm{N} 080^{\circ} \mathrm{E}, \sigma 3 \mathrm{~N} 170^{\circ} \mathrm{E}$ ) (III, Fig. 3). Because this fault set is not observed in the formations younger than the Banel Formation, and because the E-W striking normal faults are sealed by the Campagnac Formation (Vetter, 1968), this deformation is most likely middle Stephanian in age.

The fourth fault set (IV, Fig. 3) provides the best time-constraint in this study, because it consists mainly of syn-sedimentary faults at the bottom of the middle 
Stephanian Campagnac Formation. Syn-sedimentary faulting is indicated by the change of thickness of sedimentary layers against the faults, from decimetre (Figs. $4 \mathrm{~b}$ and $4 \mathrm{c}$ ) to basin scale (Vetter, 1968, Fig. 4f), by the progressive tilting of the sediments towards the NE border of the Decazeville basin (Fig. $4 \mathrm{~d}$, compare Figs. $4 \mathrm{a}$ and $4 \mathrm{c}$ ), and by the coincidence of this tilt with the slip on normal faults (Fig. 4e). This deformation also affected pelites from the Banel Formation before their diagenesis, and produces hydroplastic faults (RD218, Fig. 3). While the three first sets of faults belong to strike-slip regimes that affected the whole area, the fourth set originated in an extensional regime ( $\sigma 1$ vertical, $\sigma 3$ trending $\left.\mathrm{N} 025^{\circ} \mathrm{E}\right)$ observed only in the Decazeville basin and surrounding basement, with numerous and thick hydrothermal veins (Ruau, Fig. 3).

Finally, the youngest observed fault set consists of NNW-SSE dextral strikeslip faults, that postdate the synsedimentary faults. This last faulting belongs again to a strike-slip regime, with $\sigma 1$ and $\sigma 3$ trending $\mathrm{N} 015^{\circ}$ and $\mathrm{N} 095^{\circ}$, respectively (V, Fig. 3). This last stage is not dated, but can hypothetically be related to the Cainozoic Pyrenean tectonism, also described in the southern Massif Central, in the Aquitaine and Paris basins (Blès et al., 1989).

\section{Interpretation}

\section{Successive states of stress}

The two first stages of faulting are compatible with a dextral slip on the Argentat fault associated with a sinistral slip on the Sillon houiller fault. The observed rotation of the strike of the principal stresses may be due to a change from the pre-eminence of the Sillon houiller fault with mainly sinistral strike-slip faults striking $\mathrm{N} 020^{\circ} \mathrm{E}$, to the pre-eminence of the Argentat fault with mainly dextral strike-slip faults trending $\mathrm{N} 140^{\circ} \mathrm{E}$. As the same deformations are observed on both sides of these two major faults, they may have been conjugated at this time, in a strike-slip regime with a N-S trending $\sigma 1$ and an E-W trending $\sigma 3$. During this stage of deformation, tentatively dated middle Stephanian, it is then unlikely that the Sillon houiller fault was a main limit (as for early and middle Carboniferous times) between two domains with distinct tectonic regimes (Burg et al., 1990; Costa, 1992).

The third stage of faulting shows an inversion of the sense of shear on the two main fault directions, and a $90^{\circ}$-rotation of horizontal principal stresses, with the maximum and minimum principal stresses trending E-W and N-S, respectively. This deformation is probably related to a short-lived event, because it postdates a previous middle Stephanian deformation, and is sealed by younger middle Stephanian sediments. This event marked an important change in the tectonic regime: it was the last deformation that affected both sides of the Sillon houiller fault in the same way, and the last strike-slip regime before extensional tectonic regimes.

The fourth stage of deformation is only observed in the Decazeville basin, East of the Villefranche fault. This stage also started during middle Stephanian times. 
It is associated with an increasing subsidence in the basin, dip-slip of the main faults crossing the basin, uplift and erosion of horsts inside and around the basin (Vetter, 1968). During this stage, $\sigma 1$ was sub-vertical in the basin, indicating that horizontal stresses became weaker, and $\sigma 3$ was trending NE-SW. The dip-slip faults perpendicular to the extension direction (e. g. the Bagnaud fault, Figures $1 \mathrm{~b}$ and 1d) only affected the sedimentary cover (Vetter, 1968). Most of the observed faults are transtensive, and the main N-S striking faults were left-lateral strike-slip faults, as those defining the Lugan-Bramarigues horst (Figures $1 \mathrm{~b}$ and 1d) (Genna et al., 1999). The increasing tilt of the sediments from the axis of the basin towards its northeastern boundary (Figure 4d) indicates that these N-S strike-slip faults accommodated most of the extension and associated tilt.

\section{Relationship between the Sillon houiller fault and the Decazeville basin}

The left-lateral strike-slip displacement is observed along the entire $\mathrm{N} 020^{\circ} \mathrm{E}$ Sillon houiller fault, and was probably coeval with the numerous Stephanian basins that gave the name to this structure (Letourneur, 1953). Contemporaneous slip of strike-slip and normal faults accommodating NE-SW extension, together with the apparent lack of this deformation West of the Sillon houiller, exclude a uniform state of stress at regional scale. A hypothesis to explain both the change of strike of the strike-slip faults (from $\mathrm{N} 020^{\circ} \mathrm{E}$ along the Sillon houiller to N-S in the Decazeville basin), and the change of tectonic regime (from strike-slip along the Sillon houiller to extension in the basin), is that the Decazeville basin may be controlled by a horse-tail splay at the southern end of the Sillon houiller fault. In such a structure, transtension is the local tectonic regime, with an extensional direction similar to the one associated with the main strike-slip fault (Fig. 5). This interpretation implies that the Villefranche fault is not the southern prolongation of the Sillon houiller, as proposed on the basis of the alignment of the two faults (e;g. Cogné et al., 1966). However, several authors argued that the Villefranche fault is the southern prolongation of the Argentat fault (Mouret, 1910; Raguin, 1928), and that the sub-vertical mylonite zone, observed on the western border of the Sillon houiller across the whole Massif Central, can be followed on the western border of the Decazeville basin, before it vanishes in several branches southward (Letourneur, 1953; Raguin, 1928). Anyway, as Cainozoic sediments cover the contact between the Argentat, Sillon houiller and Villefranche faults, this problem is still unsolved.

\section{Folding in the Decazeville basin}

As shown by the comparison between Figure 2 and states of stress I, II and III in Figure 3, the fault sets and the evolution of the state of stress described in this study are in good agreement with those published previously at the Massif Central scale (Bonijoly and Castaing, 1983; Blès et al., 1989), with the same counterclockwise rotation of $\sigma 1$ from N-S to E-W. However, the interpretations differ concerning the age of deformation and for the relationships between deformations and subsidence and sedimentation:

- Bonijoly and Castaing (1983) and Blès et al. (1989) postulated that the N-Sstriking folds which involved the younger Stephanian sediments are coeval with 
the faulting associated to E-W compression. Consequently, they proposed that this deformation postdates the late Stephanian.

- This study shows that E-W compression predates NE-SW extension, which is coeval with maximum subsidence during the late Stephanian in the Decazeville basin. Consequently, folding of the late Stephanian sediments cannot be contemporaneous with the faulting related to E-W compression.

A reappraisal of the observations made by Vetter (1968) in the Decazeville basin can solve this contradiction:

a) The three late sedimentary units (Banel, Campagnac and Bourran Formations) exhibit independent fold sets: each formation is folded but the boundaries between the formations are not folded. Within the Banel Formation, Vetter (1968) describes tight anticlines that are overlain by unfolded sediments. The Bourran Formation lies unconformably on the Campagnac Formation at least locally (Fig. 6b); and the Bourran Formation itself is folded above this unconformity. However, the folds are similar in shape and trend in all formations (for example, Combes and Lassale anticlines, Figures $1 \mathrm{~b}$ and $1 \mathrm{~d}$ ). Consequently, there is no single folding phase, but three similar folding events, separated by unconformities at least locally.

b) The folds prolongate normal faults, or are cut by normal faults (Fig. 6), or are spaced with the same wavelength as normal faults (for example Dôme 1 fold, Figure 6c). Moreover, the normal faults do not seem to be folded. The axial planes of the anticlines are systematically parallel to the normal faults that affected the same formation (Fig. 6). Anticlines often developped with their axial surfaces parallel to the normal faults. In contrast, synclines are very open folds (Fig. 6). In anticlines, only coal seams appear to be folded; however, this can be an artefact resulting from mapping restricted to coal layers and few stratigraphic markers in coal mines.

c) The coal seams always thicken in the anticlines. As an example, the thickness of the 'grande couche de Bourran' exceeds $40 \mathrm{~m}$ in the anticline of Lassale, while there are only few metres of coal in the adjacent syncline (Fig. 6a). However, there are no facies variations inside, above, or below the coal seams.

d) Coal is extremely ductile: Vetter (1968) reports unused galleries rapidly filled by the upwelling of the underlying coal. In the folds, the coal exhibits fluidal textures from decimetre to millimetre scale, especially in fold hinges where many extrusion structures were found. Durand (1933) points out the coal diapirism in the anticlines, and Vetter (1968) also indicates that folding is amplified by coal migration from the synclines to the anticlines.

To explain the folds of the Decazeville basin by E-W compression implies that three phases of E-W compression occurred between the end of the middle Stephanian and the Autunian unconformity, and that each compressional phase was followed by an extensional phase. I propose an alternative explanation that does not require so many tectonic phases: in a steady-state extensional or transtensional environment, detrital sediments and coal layers accumulated in 
half-grabens bounded by normal faults. As the sedimentary loading increases, the coal flows laterally and rises along the normal faults. This flow explains the apparent thinning of the coal seams in the synclines (half-graben), and their thickening in the anticlines, against the horsts. As examples, the Passelaygues anticline (Fig. 6b and 6c) may result from the ductile flow of the coal along the Parc fault, and the Dôme 1 fold (Fig. 6c) may be injected in the Rulhe normal fault, that prolongates the fold southward.

\section{Discussion}

The new data and structural interpretations presented above can be used to discuss two points at the Massif Central scale: what is the geodynamic meaning of the Sillon houiller fault and what were the causes of the tectonic evolution during Stephanian times?

\section{The Sillon houiller, a Stephanian transfer fault?}

The idea that the Sillon houiller was a transfer fault between two domains with different extension directions was first proposed by Burg et al. (1990). Faure and Becq-Giraudon (1993), and Faure (1995) proposed that during the Stephanian, the Sillon houiller fault accommodated a difference in the amount of extension, which was more important in the eastern (numerous Stephanian basins, controlled by normal and strike-slip faults, and with rapid subsidence) than in the western part of the Massif Central (few Stephanian basins, with little subsidence and tectonic control) (Fig. 1a).

Such a transfer fault follows the definition given by Gibbs (1984). It implies variations of displacement along its strike (e.g. Figure 7a, with no displacement at the southern end of the Sillon houiller, and increasing left-lateral shear northward), and possibly changes in shear direction. This does not seem compatible with the left-lateral displacement in the Decazeville basin (Genna et al., 1999), and with a similar displacement all along the Sillon houiller fault during the formation of Stephanian basins (Letourneur, 1953).

Today the Sillon houiller is a lithospheric boundary between the eastern and western parts of the Massif Central (Granet et al., 1997; Granet et al., 2000; Babuska et al., 2002). This lithospheric boundary probably appeared during the main strike-slip displacement on the Sillon houiller fault, in Westphalian times (Lerouge, 1988). During middle and late Stephanian times, this lithospheric structure acted again as a vertical boundary that localized the deformation between the deformed eastern and the little deformed western Massif Central. Rather than a transfer fault, the Sillon houiller exhibits the main characteristics of a transform fault: along this lithospheric fault, the left-lateral displacement was constant, and the Sillon houiller was connected at both ends with a rifted area that accommodated the same amount of displacement (Fig. 7b). Southward, the horsetail splay in the Decazeville basin may represent the connection between the Sillon houiller fault and the contemporaneous E-W-trending basins of the southeast Massif Central. These basins [Détroit de Rodez (Bonijoly and Castaing, 
1983), Saint Affrique basin (Maugenest and Vinchon, 1989; Legrand et al., 1991), Graissessac basin (Becq-Giraudon and Van den Driessche, 1993)] accommodated NE-SW extension parallel to the Sillon houiller during late Stephanian and Permian times. The northern connection of the Sillon houiller may be located in the Bourbonnais, where numerous Stephanian basins (Meaulnes, Commentry, Doyet, Aumance, Noyant, Decize-La Machine, Figure 1a) also accommodated extension parallel to the Sillon houiller (Faure, 1995). This transform fault activity stopped at the end of the Stephanian, as Permian sediments seal the northern end of the fault (Letourneur, 1953). During Permian times, the extensional regime extended to the whole west European area (Ménard and Molnar, 1988), including the western part of the Massif Central: at this time, the Sillon houiller was no more a main boundary in the Massif Central.

\section{Tectonic evolution during Stephanian times}

The sequence of Stephanian deformations recorded in the Decazeville area can be reconstructed as follows, with two stages separated by a short-lived event (Fig. $8)$ :

a) During a first period that ends during the middle Stephanian, the whole Massif Central seems to react as a homogeneous block to the stress field imposed by the displacement of surrounding blocks. The stress field evolution was similar at the Massif Central scale (Blès et al., 1989) as well as at the Decazeville basin scale. The strike-slip tectonic regime ( $\sigma 1$ and $\sigma 3$ horizontal) may result from a $\mathrm{N}$ $\mathrm{S}$ convergence with an E-W escape (Fig. 8a). The $35^{\circ}$ counterclockwise rotation of the principal stresses (Fig. 8b) may result either from a rotation of the stress field in this part of the Hercynian orogen, as suggested by Bonijoly and Castaing (1987) or Blès et al. (1989), or from a decrease of the N-S stress due to the end of the N-S convergence.

b) A short-lived event occurred during the middle Stephanian, with a strike-slip tectonic regime ( $\sigma 1$ and $\sigma 3$ striking $\mathrm{N} 080^{\circ}$ and $\mathrm{N} 170^{\circ}$, respectively, Fig. 8c). This event marked an important change in the orientation of the principal stresses, with a permutation between the maximum and minimum principal stresses. It also marked the end of compression at the Massif Central scale. The origin of this tectonic event is not clear: it may be related to a reorganization of block displacements in the orogenic belt after the end of the collision. This event may be contemporaneous with the end of the drift of the African craton to the south of western Europe (Matte, 1986), or with the initiation of dextral mega-shear zones south of Europe to accommodate the translation between Africa and Europe during Stephanian times as proposed by Bard (1997).

c) From middle to late Stephanian, the eastern and western parts of the French Massif Central became independant blocks on each side of the Sillon houiller fault, from the Bourbonnais area in the North to the Decazeville basin in the South (Fig. 8d). The relative displacement between these two blocks is located along the Sillon houiller fault and at its ends. The left-lateral displacement on the Sillon houiller fault is associated with NE-SW extension that affected the whole eastern Massif Central, and produced a rapid subsidence in the Decazeville basin. As in 
the Ales (Djarar et al., 1996) or St Etienne basins, the sediments of the Decazeville basin are deformed by gravity-driven folding. A similar NE-SWtrending extension occurred during Stephanian and Autunian times in the Decazeville area, and suggests the continuity of the late orogenic extension through the Carboniferous-Permian boundary as in the Graissessac basin (BecqGiraudon and Van den Driessche, 1993). However, since the Permian, the Sillon houiller fault was inactive, and the extension reached the western part of the Massif Central.

\section{Conclusions}

- From middle to late Stephanian times, the Sillon houiller fault was a lithospheric fault which accommodated a constant displacement between two extensional areas, the Bourbonnais in the north and the E-W-striking basins of the southern Massif Central. The contemporaneous strike-slip and normal faults of the Decazeville basin can be explained as a horse-tail splay, at the southern intersection of the Sillon houiller fault and the extensional basins.

- Before and during middle Stephanian times, the Massif Central probably deformed as a single block in a regional strike-slip regime, including slip on several parts of the Sillon houiller and Villefranche fault. The transition between the late-orogenic deformation ( $\sigma 1$ horizontal at a regional scale) to the postorogenic deformation ( $\sigma$ l vertical at a regional scale) occurred during middle Stephanian time. From the middle to late Stephanian, the tectonic regime is not uniform, with the Sillon houiller strike-slip fault as the main boundary between a little deformed western block and an eastern one with NE-SW extension. During the Permian, extension affected the whole belt.

- Folding in the Decazeville basin, previously interpreted as late Stephanian EW compression, may have resulted from ductile flow of coal along normal faults during basin formation.

- Finally, this study has also some implications on the formation of coal measures: the unusual thickness (up to 60 meters) of coal seams in the Decazeville basins is probably related to coal diapirism. As for hydrocarbons, migration can create or improve the economic importance of coal fields.

\section{Acknowledgements}

I would like to thank J.P. Bouillin and G. Mascle for fruitful discussions on the palaeogeography at the end of Palaeozoic. M. Faure, J.S. Grimmer and V. Wrede provided pertinent and constructive remarks on several versions of the manuscript. I am grateful to R.O. Greiling for his editorial work that improved the manuscript. 


\section{References}

Angelier J (1990) Inversion of field data in fault tectonics to obtain the regional stress-III. A new rapid direct inversion method by analytical means. Geophys J Int 103: $363-376$

Arthaud F, Matte P (1977) Late Paleozoic strike-slip faulting in southern Europe and northern Africa: result of a right-lateral shear zone between the Appalachians and the Urals. Geol Soc Am Bull 88: 1305-1320

Babuska V, Plomerova J, Vecsey L, Granet M, Achauer U (2002) Seismic anisotropy of the French Massif Central and predisposition of Cenozoic rifting and volcanism by Variscan suture hidden in the mantle lithosphere. Tectonics 21 , 4: $1-20$

Bard JP (1997) Démembrement anté-mésozoïque de la chaîne varisque d'Europe occidentale et d'Afrique du Nord: rôle essentiel des grands décrochements transpressifs dextres accompagnant la rotation-translation horaire de l'Afrique durant le Stéphanien. C R Acad Sci Paris 324: 693-704.

Becq-Giraudon JF (1993) Problèmes de la biostratigraphie dans le Paléozoïque supérieur continental (Stéphanien - Autunien) du Massif Central. Geodin Acta 6: 219-224

Becq-Giraudon JF, Van den Driessche J (1993) Continuité de la sédimentation entre le Stéphanien et l'Autunien dans le bassin de Graissessac-Lodève (sud du Massif Central): implications tectoniques. C R Acad Sci Paris 317: 939-945

Blès JL, Bonijoly D, Castaing C, Gros Y (1989) Successive post-Variscan stress fields in the French Massif Central and its borders (Western European plate): comparison with geodynamic data. Tectonophysics 169: 79-111

Bonijoly D, Castaing C (1983) Fracturation et genèse des bassins stéphaniens du Massif Central français en régime compressif. Ann Soc Geol Nord 103: 187199

Bonijoly D, Castaing C (1987) Ouverture et évolution structurale de quelques bassins houillers de directions orthogonales, dans le Massif Central français. Ann Soc Geol Nord 106: 189-200

Broutin J, Doubinger J, Langiaux J, Primey D (1986) Conséquences de la coexistence de flores à caractères stéphaniens et autuniens dans les bassins limniques d'Europe occidentale. Mém Soc Géol Fr NS 149: 15-25

Bruguier O, Becq-Giraudon JF, Bosch D, Lancelot JR (1998) Late Visean hidden basins in the internal zones of the variscan belt: U-Pb zircon evidence from the French Massif Central. Geology 26: 627-630

Burg JP, Brun JP, Van den Driessche J (1990) Le Sillon houiller du Massif Central français: faille de transfert pendant l'amincissement crustal de la chaîne varisque? C R Acad Sci Paris 311: 147-152

Chantraine J, Autran A, Cavalier C, Alabouvette B, Barféty JC, Cecca F, 
Clozier L, Debrand-Passard S, Dubreuilh J, Feybesse JL, Guennoc P, Ledru P, Rossi P, Ternet Y (1996) Carte géologique de la France à l'échelle du millionième, 6ème édition, BRGM, Orléans

Cogné J, Gèze B, Goguel J, Grolier J, Letourneur J, Pellet J, Rothé J, Sittler C (1966) Les rifts et les failles de décrochement en France. Rev Geog Phys Geol Dyn 8: 123-131

Costa S (1992) East-west diachronism of the collisional stage in the french Massif Central: implications for the European Variscan Orogen. Geodin Acta 5: $51-68$

Djarar L, Wang H, Guiraud M, Clermonté J, Courel L, Dumain M, Laversanne J (1996) Le bassin stéphanien des Cévennes (Massif Central): un exemple de relation entre sédimentation et tectonique extensive tardi-orogénique dans la chaîne varisque. Geodin Acta 9: 193-222

Durand J (1933) Sur l'existence de phénomènes de diapirisme dans le bassin houiller de Decazeville. C R Som Soc Géol Fr 18-19

Faure M (1995) Late orogenic carboniferous extensions in the Variscan French Massif Central. Tectonics 14: 132-153

Faure M, Becq-Giraudon JF (1993) Sur la succession des épisodes extensifs au cours du désépaississement carbonifère du Massif Central français. C R Acad Sci Paris 316: 967-973

Feix I, Guillot PL, Miyashita S, Bossière G, Floc'h JP (1987) Arguments en faveur d'un épisode majeur en cisaillement dextre le long de la faille d'Argentat (Massif Central). Conséquences. C R Acad Sci Paris 305: 473-476

Genna A, Debriette PJ, Robelin C (1999) Les fractures en gradins: critères cinématiques de la déformation précoce des sédiments. Bull Soc Geol Fr 170: 569-577

Genna A, Roig JY, Debriette PJ, Bouchot V (1998) Le bassin houiller d'Argentat (Massif Central français), conséquence topographique d'un plissement de son substratum varisque. C R Acad Sci Paris 327: 279-284

Gibbs AD (1984) Structural evolution of extensional basin margins. J geol Soc London 141: 609-620

Granet M, Glahn A, Achauer U (1997) Anisotropic measurements in the Rhine graben area and the French Massif Central: geodynamic implications. Pure Appl Geoph 151: 333-364

Granet M, Judenher S, Souriau A (2000) Des images du système lithosphèreasthenosphère sous la France et leurs implications géodynamiques: 1'apport de la tomographie telesismique et de l'anisotropie sismique. Bull Soc Geol Fr 171: 149167

Grolier J, Letourneur J (1968) L'évolution tectonique du grand Sillon houiller du Massif Central français. XXIIİ̀me Congrès Géologique International 1: 107-116 
Legrand X, Soula JC, Rolando JP (1991) Un modèle de développement d'un roll-over complexe: la bordure sud du bassin de Saint Affrique (Sud du Massif Central français). C R Acad Sci Paris 312: 1625-1631

Lerouge G (1988) Tectogenèse comparée de deux segments de la chaîne hercynienne: le Massif Central français septentrional et le Sud du Massif Armoricain. Mém Géodiffusion 2: 1-363

Letourneur J (1953) Le grand Sillon houiller du Plateau Central français. Bull Serv Carte Géologique de la France 51: 1-236

Matte P (1986) La chaîne varisque parmi les chaînes paléozoïques périatlantiques, modèle d'évolution et position des grands blocs continentaux au Permo-Carbonifère. Bull Soc Geol Fr 8: 9-24

Maugenest MC, Vinchon C (1989) Le Permien de Saint-Affrique. In: Chateauneuf JJ, Farjanel G (Eds). Synthèse géologique des bassins permiens français. Mem BRGM 128: 100-105

Ménard G, Molnar P (1988) Collapse of a Hercynian Tibetan Plateau into a late Paleozoic European Basin and Range province. Nature 334: 235-237

Mouret G (1910) Note sur le prolongement probable vers le Sud, du chenal houiller de Mauriac. Bull Soc Geol Fr 829-839

Raguin E (1928) Etude tectonique dans les terrains cristallins situés au voisinage du Grand Sillon houiller du Plateau Central français. Bull Soc Géol Fr $189-225$

Roig JY, Calcagno P, Bouchot V, Maluski H, Faure M (1997) Modélisation 3D du paléochamp hydrothermal As + Au (330-300 Ma) le long de la faille d'Argentat (Massif Central français). Chron Rech Min 528: 63-69

Vetter P (1968) Géologie et paléontologie des bassins houillers de Decazeville, de Figeac et du détroit de Rodez. Houillères du Bassin d'Aquitaine, Albi, pp. 1637

Vetter P (1981) Le bassin de Decazeville. Bull Centres Rech Explor-Prod ElfAquitaine 5: 701-717

\section{Figure captions}

Figure 1: a: Map of the French Massif Central. Boundaries and faults from Chantraine et al. (1996). Only the main strike-slip and normal faults are indicated. b: Simplified map of the Decazeville basin (modified from Vetter, 1968 ; located Fig. 1a). Studied outcrops (Fig. 3) are indicated in capital letters; location of sections (Fig. 1d, Fig. 6) are indicated by white lines. c: Synthetic lithostratigraphic column of the Decazeville basin (modified from Vetter, 1981). The 333 Ma-old sample (Bruguier et al., 1998) is not precisely located. d: Section 
of the Decazeville basin (modified from Vetter, 1968); same legend as for Figure $1 b$; main coal seams in black in the Bourran and Campagnac Formations.

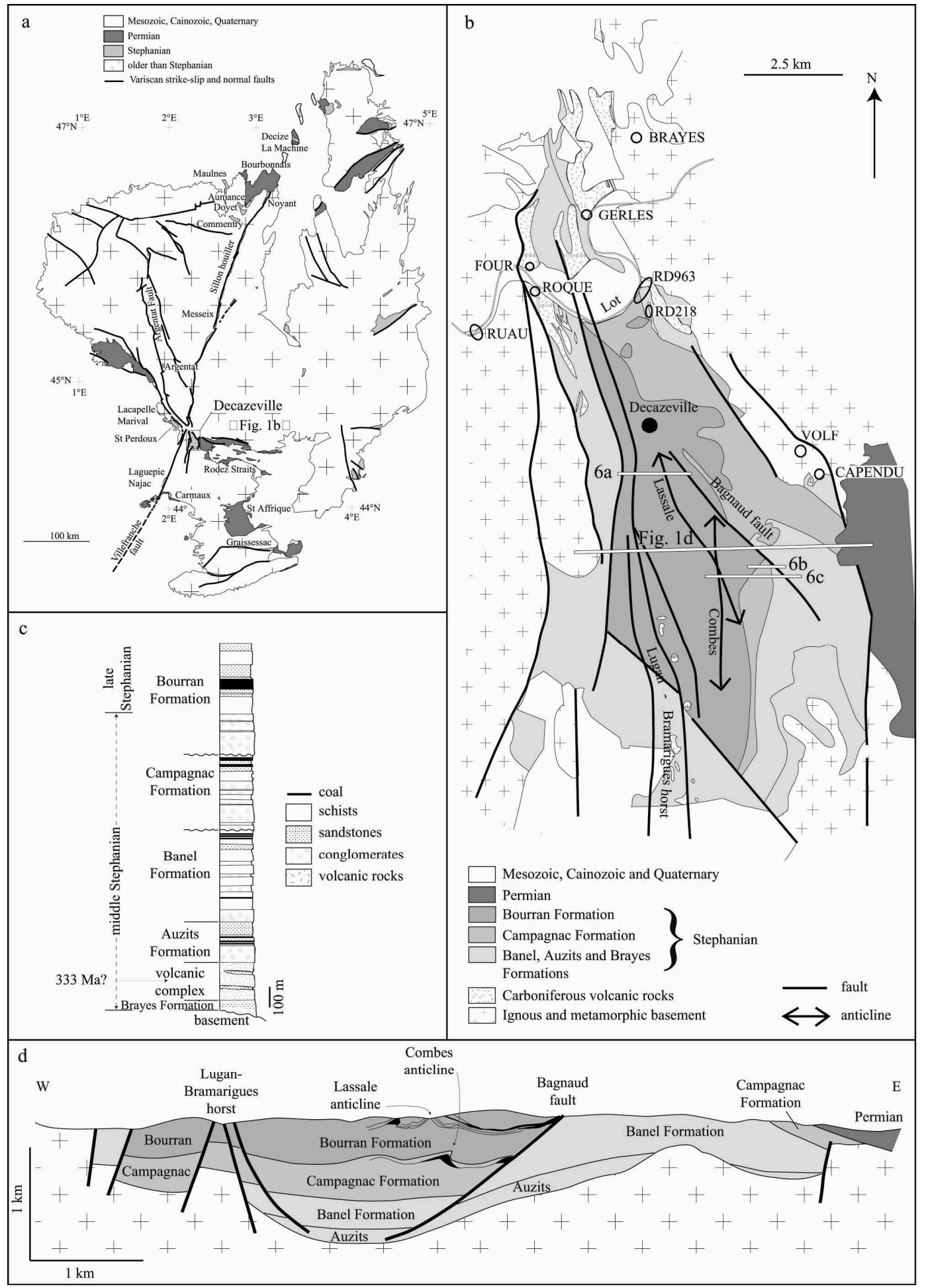


Figure 2: Directional data of three phases of deformation as described by Bonijoly and Castaing (1983) and Blès et al. (1989). a: N-S compression from late Westphalian to middle Stephanian times. b: NW-SE compression from the end of the middle Stephanian to the beginning of the late Stephanian. c: E-W compression during the late Stephanian. Barbed lines indicate reverse faults and folds; double arrows indicate strike-slip faults. The grey area indicates the distribution of strike for each set of faults or folds.
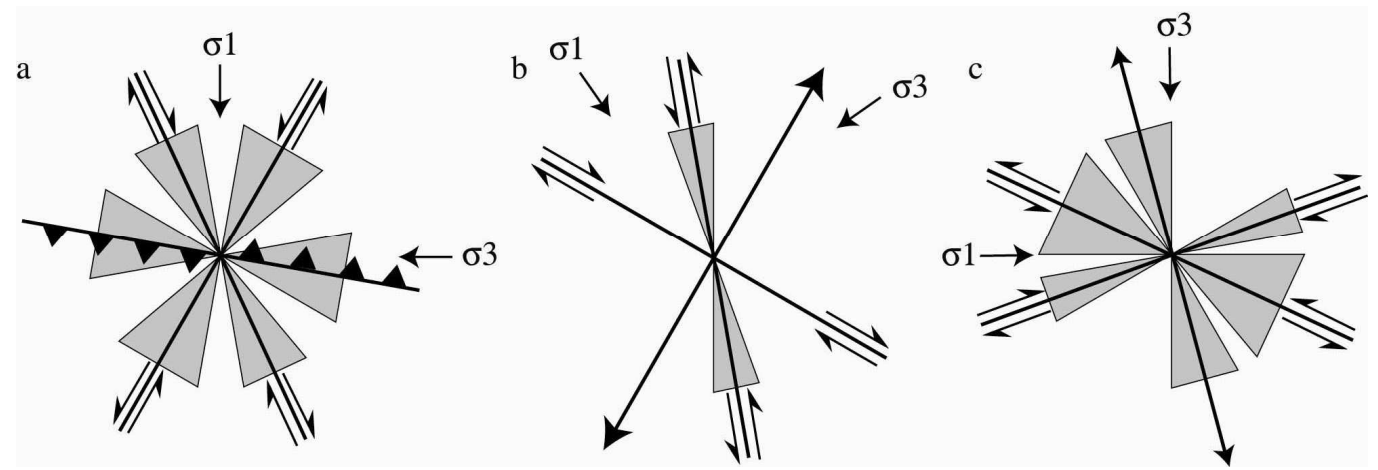

Figure 3: Microstructural data and stress evolution around the Decazeville basin. For the synthesis (top line), same legend as for Figure 2. Location of sites is marked on Figure 1b, except Bois in Lacapelle-Marival basin (Lambert III coordinates $\mathrm{X}: 568, \mathrm{Y}: 3268$ ). At each site, the faults are correlated with one of the seven stress fields. All projections use Wulff net, lower hemisphere. The principal stresses $\sigma 1, \sigma 2$ and $\sigma 3$ are shown (when determined) by 5, 4 or 3branched stars, respectively. The horizontal arrows that link the stereonets indicate the chronology as observed in the field. Additional stereonets show the orientation of microfold axes (open circles), veins (great circles) and associated fibres (black circles). 
figure 3

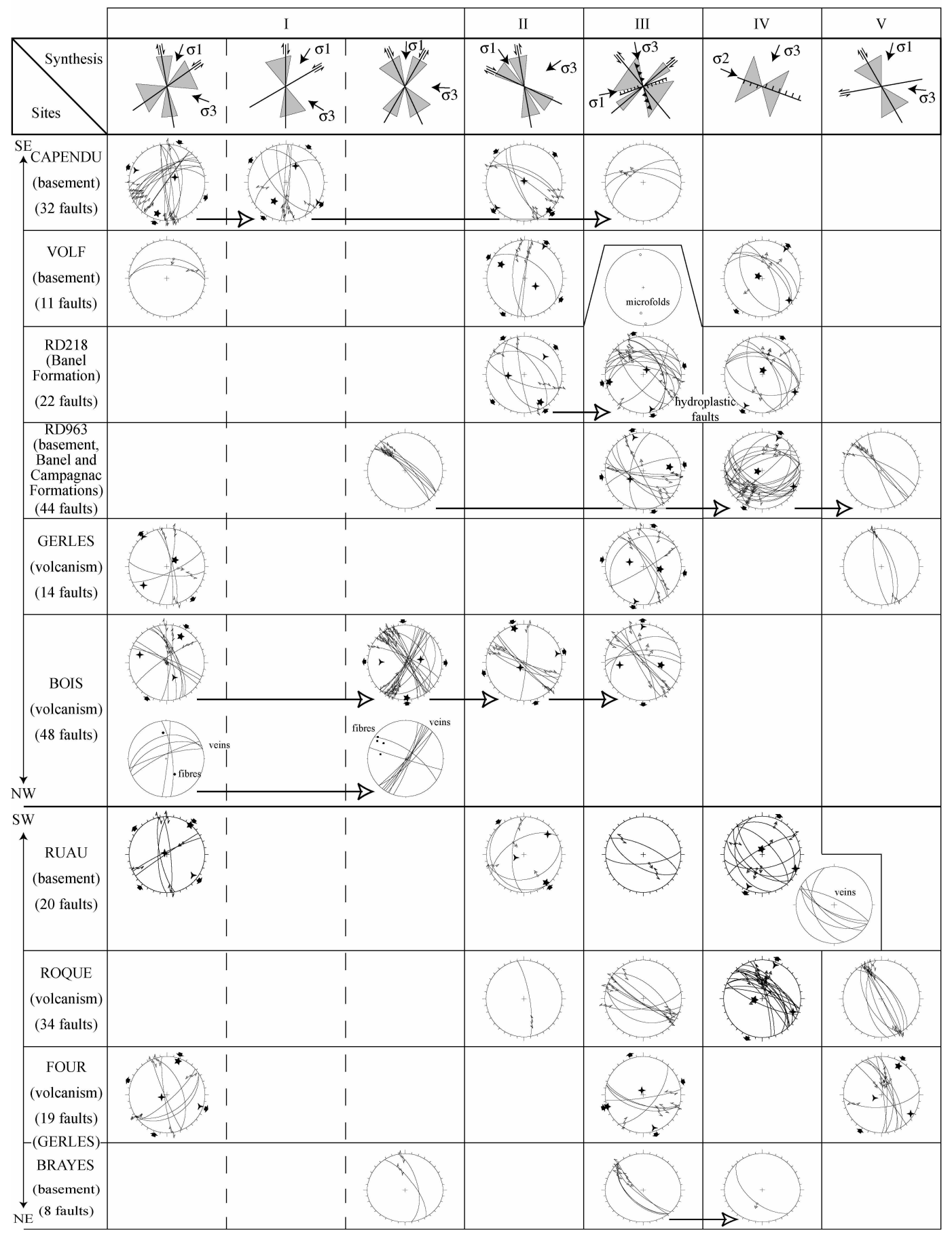


Figure 4: Syn-sedimentary deformation in northern part of the Decazeville basin. a, b and c are photographs from site RD 963 (location on Fig. 1b), from 50 $\mathrm{m}$ from the NE border of the basin (a, note the dip of the layers) towards $1 \mathrm{~km}$ from the NE border of the basin ( $b$ and $c$ ). In $b$ and $c$, note the variation of thickness of the layers against the normal faults (cliff height around $6 \mathrm{~m}$ ). $\mathrm{d}$ shows the progressive rotation of the bedding ( $\mathrm{s} 0$ ) from the border towards the centre of the basin in site RD 963, and the best great circle that fits the trace of this rotation; e shows syn-sedimentary normal faults associated with this rotation (stage IV, cf. Fig. 3). Note the coincidence of the trace of the rotation, the slip on the faults and the extension direction. $\mathrm{d}$ and e are wulff nets, lower hemisphere projections. $\mathrm{f}$ (modified from Vetter, 1968): reconstitution of geometric relationships between the base of the Campagnac Formation and older sediments (section at Decazeville's latitude). Note the westward tilt of the Banel Formation and the normal faults sealed by the Campagnac Formation. The fault bounding the LuganBramarigues horst was again active during deposition of the Campagnac and Bourran Formations. 

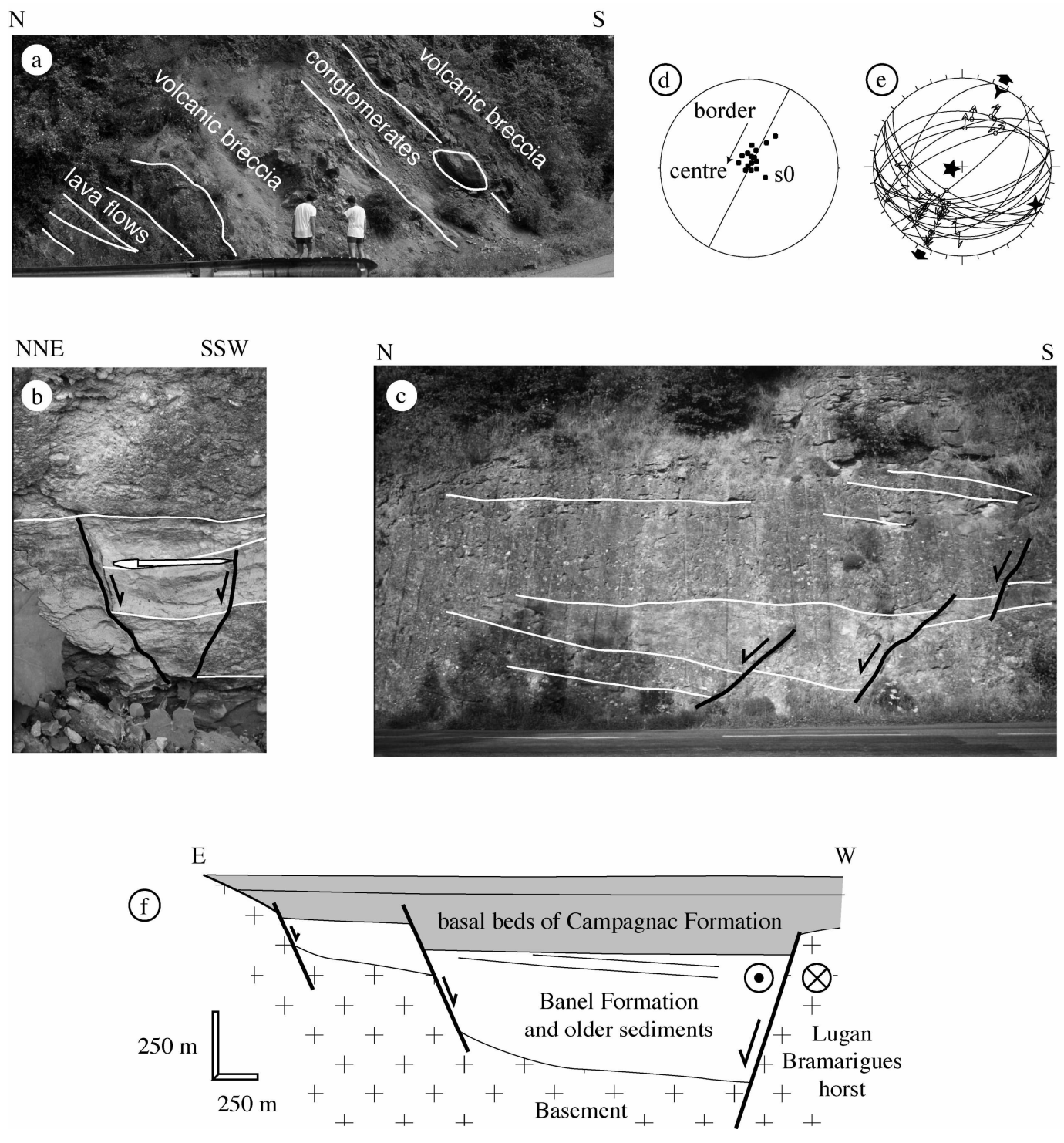

Figure 5: Structural sketch showing the Decazeville basin as formed by a horse-tail splay at the southern end of the Sillon Houiller fault, and associated variations of the state of stress. 
Figure 5

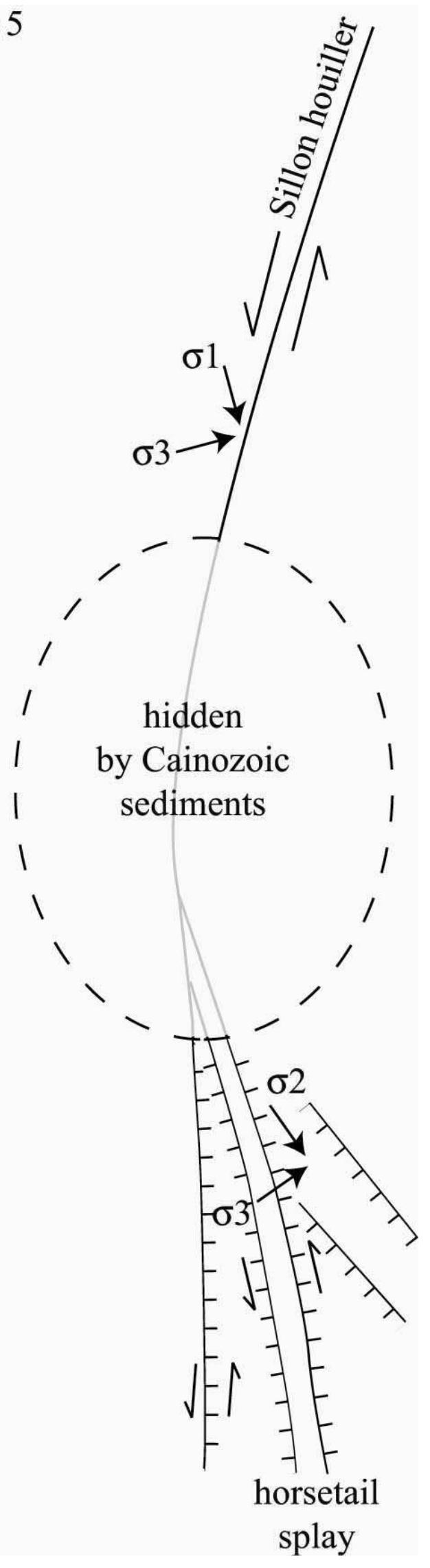


Figure 6: Three E-W sections across the Decazeville basin (modified from Vetter, 1968). Location on Figure 1b. In grey, coal seams. The asymmetric fold at Dôme 1 (Fig. 6c) is the northward prolongation of the Rulhe normal fault.

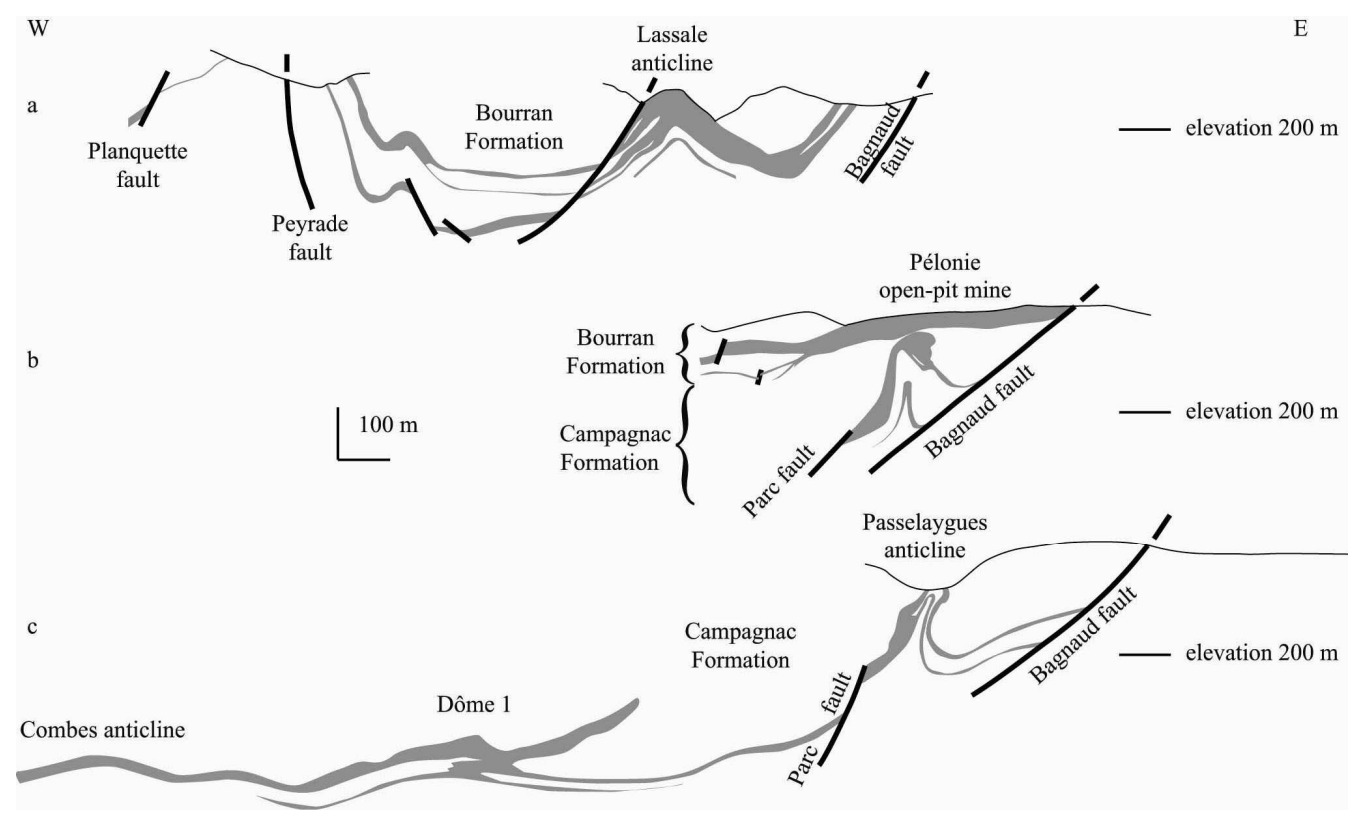


Figure 7: The Sillon houiller as a transfer or transform fault during the late Stephanian. SH: Sillon houiller; the lengths of white double arrows indicate the amount of extension, the lengths of thin arrows indicate the Stephanian slip on the Sillon houiller fault. a: the Sillon houiller as a transfer fault (Faure, 1995): the southern end of the fault is supposed to be fixed (otherwise the fault is dextral), and the slip increases northward. b: the Sillon houiller as a transform fault: the slip is constant all along the fault between the divergent zones northward (Bourbonnais) and southward (Rodez Straits).
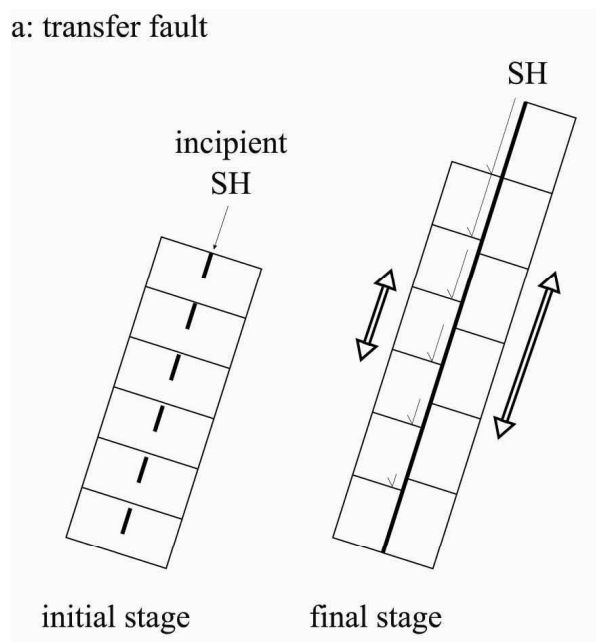

b: transform fault

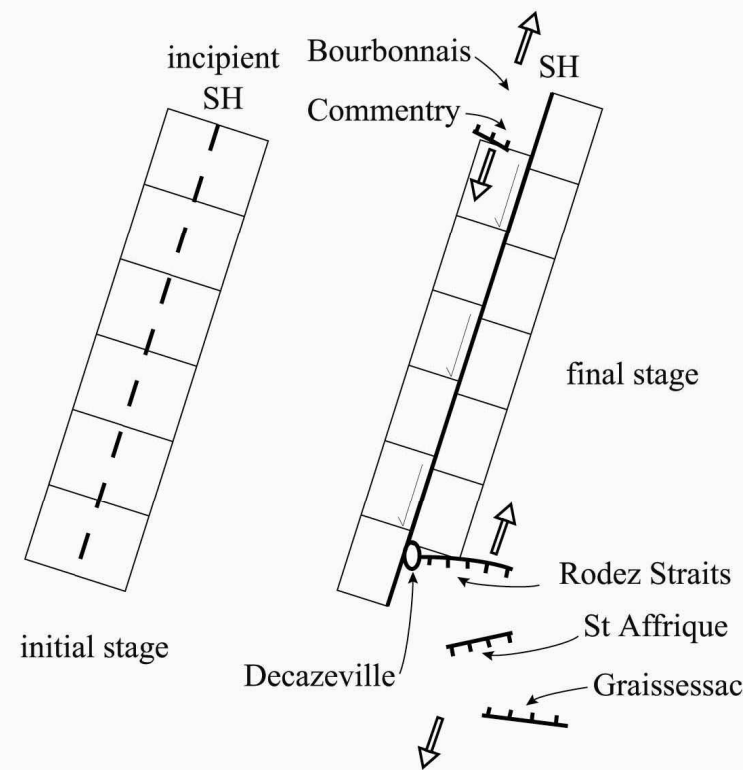

Figure 8: Schematic evolution of the state of stress within the French Massif Central during Stephanian times. From a to c, the state of stress is homogeneous in the Massif Central. c shows a short episode with inversion of strike-slip motions on the Sillon houiller and the Argentat fault. d: the Massif Central is cut in two blocks by the Sillon houiller, thought to be a transform fault between two divergent areas.
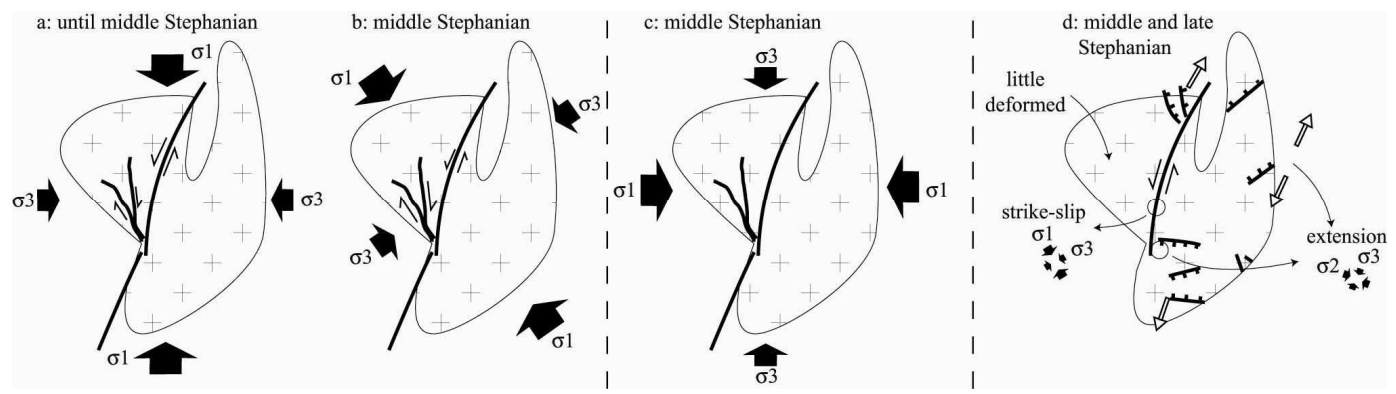